\title{
COMPARATIVE ANALYSIS OF SUSTAINABLE REAL ESTATE MARKET DEVELOPMENT IN TWO NORTHERN CAPITALS: CASE OF RIGA, LATVIA AND STOCKHOLM, SWEDEN
}

\author{
Ankit MISHRA ${ }^{1}$, Linda KAUŠKALE ${ }^{2}$ \\ ${ }^{1,2}$ Riga Technical University, Latvia \\ Corresponding author e-mail: ankit.civil.official@gmail.com
}

\begin{abstract}
Sustainable development becomes a necessary practice in every country. Real estate has always been an essential need for humans to survive, almost all human activities are related to real estate. Due to that, as well as due to the growth of population, real estate has grown in numbers in the world for our basic need fulfilment. Major studies have shown that real estate objects are one of the major contributors negatively affecting our environment. Sustainable real estate development is a crucial practice implemented by successful countries and other countries are following them, adopting good practice in this field. Sustainable real estate development analysis not only helps to solve climate change issues, but also increases asset value. The aim of the research is to analyze two northern region capitals: Riga (Latvia) and Stockholm (Sweden) and their major steps being taken to promote sustainable real estate development. The comparative, historical, logical and statistical data analysis methods have been used in the research.
\end{abstract}

Keywords: Economic factors, European Union, governance, Latvia, Riga, social factors, Stockholm, sustainability, Sweden, United Nations.

\section{INTRODUCTION}

Sustainable real estate is the type of real estate, which has low or no negative effect on the environment. In other words, green development of real estate is the concept that focuses on both social and environmental impacts of the overall development. Environmental responsiveness, resource efficiency, community and cultural sensitivity have a great impact on the green development of real estate. The aim of the research is to analyze two northern capitals - Riga (Latvia) and Stockholm (Sweden) and the major steps they take to promote sustainable real estate development. The tasks of the research are the following:

- to analyze government involvement in promoting sustainable real estate development in both cities;

- to analyze examples from the existing projects implemented in the cities;

- to make conclusions and develop recommendations.

To achieve the aim of the research, comparative, historical, logical and statistical data analysis methods have been used. 


\section{SUSTAINABILE DEVELOPMENT ISSUES, REGULATIONS AND TENDENCIES IN THE WORLD}

Based on the Corporate Sustainability Assessment (CSA), an annual environmental, social and governance analysis was conducted by RobecoSAM (2016) organization. Sustainability profile of a country is analyzed considering three main factors: Environmental, Social and Governance (ESG). World Sustainability Ranking by country is shown in Figure 1.

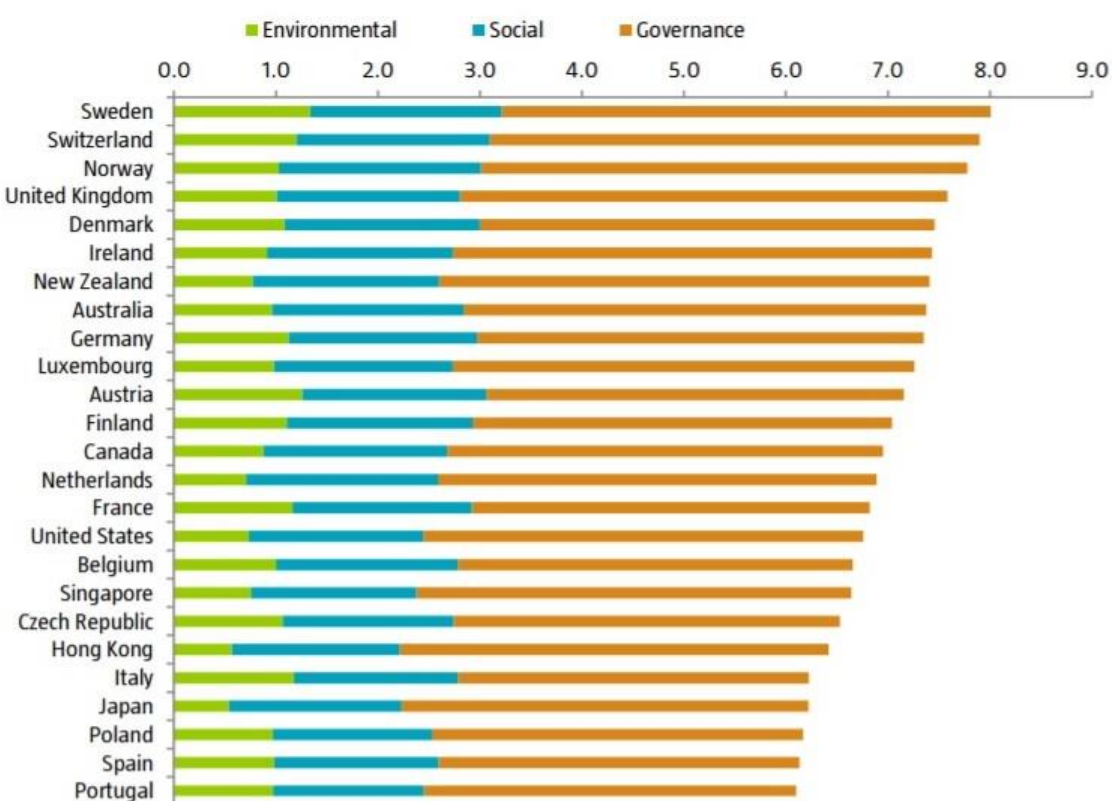

Fig. 1. World Sustainability Ranking, April 2016 (RobecoSam, 2016).

As Figure 1 shows, Sweden is on the top with Switzerland closely behind, and governance plays the key role in ensuring higher ranking in the evaluation of sustainability level.

The Coordination Unit for Sustainable Development has been established in Sweden to coordinate the work on sustainable development. The task of this unit within the Ministry of Sustainable Development is to coordinate and lead the work to facilitate implementation of the national strategy. The Unit is also responsible for development of actions of Sweden in sustainability issues, both in the European Union and the UN Commission on Sustainable Development (CSD).

According to the research article European Economic Sustainability Index, June 2010 from EPC (European Policy Centre, 2010), in 2007 Latvia was ranked $2^{\text {nd }}$ among European countries in Sustainable Economic Index, which dropped to $23^{\text {rd }}$ place in 2010, whereas, Sweden moved from the $8^{\text {th }}$ in 2007 to the $1^{\text {st }}$ place in 2010.

Sweden along with Denmark and Germany had maintained a high sustainability level for many years. 
As it was described in the Sustainable Development in the European Union, 2013 (Monitoring Report of the EU sustainable development strategy) by Eurostat Statistical Books (2013), good governance plays a vital role. It includes greening taxation policies and that in turn means that the government can encourage buyers to pay lower taxes for lower energy consumption. This increase in government revenues can help to reduce government deficit or lead to reduction of other taxes and most importantly it will help in achieving Europe's environmental goals.

The ten Sustainable Development Indicators developed by the report of 2013 Sustainable Development in the European Union are:

- Socioeconomic development;

- Sustainable consumption and production;

- Social inclusion;

- Demographic changes;

- Public health;

- Climate change;

- Sustainable transport;

- Natural resources;

- Global partnership;

- Good governance.

These indicators were developed to focus on the progress in reaching the objectives set by policies like Europe 2020 Strategy accounting for the recent changes in Europe.

India aims to develop 20 percent of its new households to be green by 2020 according to an article named Sustainable Housing Leadership Consortium by European External Action Service (2017). These 20 percent of new houses will be able to save 198 million $\mathrm{kWh}$ per year, which will be enough to power 100,000 homes. It will also help in saving 108 billion liters of water and it will reduce India's carbon footprint, which means reduction of carbon-dioxide by 0.2 million metric tons.

The plan released by the United Nations named "Transforming our World: The 2030 Agenda for Sustainable Development (September 2015)" highlights 17 goals, their sole purpose is to achieve sustainability in many areas in the world by 2030 . These 17 global goals are:

- No poverty;

- Zero hunger;

- Good health and well-being;

- Quality education;

- Gender equality;

- Clean water and sanitation;

- Affordable and clean energy;

- Decent work and economic growth;

- Industry, innovation and infrastructure;

- Reduced inequality;

- Sustainable cities and communities; 
- Responsible consumption and production;

- Climate action;

- Life below water;

- Life on land;

- Peace and justice strong institutions;

- Partnership to achieve the goals.

Sustainable real estate object analysis in Sweden is conducted in the next part.

\section{SUSTAINABLE REAL ESTATE DEVELOPMENT IN SWEDEN}

Sweden is a thinly populated country and has a long coastline, numerous forests and lakes. The population of the country is 10 million, which is 0.13 percent of the world population.

According to the article "Sustainable Living in Sweden" (Swedish Institute, 2016b) written in 2011, the Swedish government presented a new environmental technology strategy to establish favorable conditions for the growth and development of environmental technology companies, and set three main objectives:

- to promote the export of Swedish environmental technology and thus contribute to sustainable economic growth in Sweden and globally;

- to promote research and innovation in environmental technology and create the conditions required for green technology companies to flourish in Sweden;

- to make it easier to commercialize innovations.

This strategy is backed by SEK 400 million (41.6 million Euro) total funding with SEK 100 million (10.4 million Euro) allocated each year from 2011 to 2014. Sweden's environmental technology sector employs roughly 40,000 people and has revenues of about SEK 120 billion (12.6 billion Euro), according to Statistics Sweden and the then Swedish Environmental Technology Council (Swedish Institute, Business Sweden, VisitSweden and the Swedish Government Offices, 2016b). According to the Swedish Institute, Business Sweden, VisitSweden and the Swedish Government Offices (2016b), in the recent years Sweden has done a great job in mobilizing and promoting awareness of their citizens on the idea of green and sustainable development. As a result, the city of Gothenburg has centralized the heating and cooling system and the district heating provides $80 \%$ of heat and hot water to the apartment blocks. A single source can be an easy way to improve into sustainable provider which mainly uses recycled heat from the industries which would otherwise go to waste.

Vaxjo, Sweden, uses centralized district cooling and heating system and back in 1996 Vaxjo became the first city in the world to set a goal of being fossil fuel free by 2030. In 2014, Vaxjo had 2.4m tonnes of carbon-dioxide emissions per capita, which was much less than the EU average of $7.3 \mathrm{~m}$ tonnes that year (Swedish Institute, Business Sweden, VisitSweden and the Swedish Government Offices, 2016b). Malmo and its surrounding region are combating climate change through forward thinking and sustainability initiatives. Vastra Hamnen, the 
western harbor of Malmo, is Europe's first termed carbon neutral neighbourhood as they use renewable sources for heating and cooling and vacuum is used to transfer household waste to an underground centralized tank. This waste is later converted into biogas fuel for the public transport. Augustenborg was awarded World Habitat Award by the United Nations in 2010 for its 10,000 green roofs and 70 percent of the collected waste recycled. The district of Hyllie has set a goal of going 100 percent on renewable and recycled energy by 2020 (Swedish Institute, Business Sweden, VisitSweden and the Swedish Government Offices, 2016b).

Umea, Stockholm, in 2008 started building more energy-efficient buildings through its Sustainable Ålidhem Revitalisation Project. 400 residential apartments were built during the 1960s and 1970s which have been refurbished with the goal of reducing their energy consumption by 50 per cent. Over 137 new apartments consume 50 per cent less energy because photovoltaic cells were built on the roofs to harness solar energy. The project went on to win the 2013 Sustainable Energy Europe Award in the 'Living' category (Swedish Institute, Business Sweden, VisitSweden and the Swedish Government Offices, 2016b).

According to the same source, building passive houses that reduces energy consumption by building low-energy residences, which power themselves using energy from people's body heat, electrical appliances and sunlight, is necessary for the society. In Helsingborg in southern Sweden, Väla Gård is a collection of solar-powered office buildings and conference rooms that are also passive-energy efficient. Completed in 2012, it has air-purifying plant walls, produces more energy than it consumes and has the highest platinum level LEED certification for green buildings.

According to "Swedish Sustainable Building 2011" (Bergström \& SaveÖfverholm, 2011) introduced at World Sustainable Building Conference held in Helsinki (2011), the assessment systems used for buildings in Sweden are the following:

- Miljöbyggnad is a Swedish assessment system adapted to Swedish conditions. Applications for Miljöbyggnad rating are handled by the Sweden Green Building Council. This non-profit organization owned by its members - the companies and organizations within the Swedish construction and property sector, aims at developing and influencing environmental and sustainability work in the industry;

- GreenBuilding is an established way of real estate assessment in the Swedish market, which is developed by the EU;

- BREEAM from Great Britain, the most used environmental assessment system in the world, is also used in Sweden.

- LEED, developed in the US and the internationally best-known assessment system.

The next part focuses on the case of Stockholm, its real estate objects and market development, with particular focus on sustainability aspects. 


\section{SUSTAINABLE REAL ESTATE IN STOCKHOLM}

Stockholm is the capital city of Sweden with the population of 789,024 in 2007, it is expected that by the year 2022 the population will reach 1 million. The land area of Stockholm is 188 square kilometers, out of which 40 percent is covered by parks and green zones. In Stockholm, there are 428,300 dwelling units, out of which 89.8 percent is multi-family houses and 10.2 percent is single family houses (Stockholm City Plan Report, May 2009).

According to the "Stockholm City Plan Report" of May 2009 by the City Planning Administration, there are four main strategies to meet the challenges and achieve the vision of the world class Stockholm:

- Strengthen central Stockholm, focusing on expanding the inner city;

- Focus on strategic nodes, developing the outer city nodes;

- Connect city areas, increasing public cohesion;

- Create a vibrant urban environment, developing the city for the future.

City of Stockholm Executive Office has a vision for Stockholm, explained in a report named Vision 2030 A Guide to the Future for Stockholm (2007), by Stockholm City Council which shall be achieved by the year 2030. This project named "Vision Stockholm 2030" contains the details of future urbanization of the city and future achievable goals, which focus mainly on long term improvements through sustainable development.

Several examples of sustainable construction in Stockholm are mentioned below (Bergström \& Save-Öfverholm, 2011; AREIM, Sustainable building Examples).

- Stockholm Waterfront has a unique energy system, which amongst other things makes use of water from Lake Klara. Inside the building there is a large ice store, which acts as an energy buffer, and it can be used both to store and extract energy. By transferring energy across time, it is possible to make use of the interaction between different buildings to minimize the amount of purchased energy. When large events take place in the Congress Centre, surplus heat is generated and this can be distributed to the office building. The energy consumption is extremely low in the entire Waterfront complex.

- The residential property on Västermalms Strand (Välbehaget 1) in Stockholm is the first residential project in Sweden that has been certified according to the LEED Gold Standard. It is one of the capital's greenest residential buildings with low energy consumption and its own geothermal power plant.

- Sjöstadsporten (Torkhuset 4) in Hammarby Sjöstad is certified as a Green Building, which means that the energy consumption is $25 \%$ lower than the requirements in the current new-build regulations. The solar panels installed on the roof generate approximately $4 \%$ of the energy consumed in the building. 
- Pelarbacken and Havsfrun were renovated in 2010. These buildings certified as Green Buildings use at least 25 per cent less energy than an ordinary newly constructed Swedish building.

- Lustgården, Stockholm, will be the first building in Stockholm to be Platinum-classified in accordance with Leadership in Energy and Environmental Design, LEED. The interesting thing about Lustgården is that the ground and foundation work will include drilling 140 holes that will be used for geo-thermal cooling. This cooling system is called Deep Green Cooling.

Stockholm Royal Seaport, Värtahamnen of Stockholm, is an industrial area and a ferry terminal. A waterfront township is being developed in this area where thousands of new homes are being developed for rental, tenant-owner and as well as student accommodation purposes. The Sweden Green Building Council has selected this area to make it Stockholm's new environmental profile districts. The vision is to create a climate positive township meeting the targets of environmental quality and sustainability to be fossil-free by 2030. Passive buildings and energyplus buildings are under construction, with self-contained water, waste disposal and energy systems. Electricity is generated by micro-production and smart power networks. Next to each dwelling unit there are more parking spaces for bikes rather than for cars (Bergström \& Save-Öfverholm, 2011).

Järva, located in the west of Stockholm, comprises Rinkeby and Tensta townships south of Järvafältet, one of Stockholm's green corridors, and the townships Kista, Husby and Akalla to the north of it, and it has roughly 60,000 residents. In connection with the upgrading of Järva's housing, energy use is to be more than halved, to $88 \mathrm{kWh} / \mathrm{m}^{2}$ annually, as compared with the national stipulation of not more than $110 \mathrm{kWh} / \mathrm{m}^{2}$ annually for new buildings. A local wind farm is also planned for Järva, and solar cells and collectors will be integrated with the buildings. The Järva Dialogue enables residents to have a say in renovation decision-making (Bergström \& Save-Öfverholm, 2011).

Sustainable real estate object development in Latvia is analyzed in the next part.

\section{SUSTAINABLE REAL ESTATE DEVELOPMENT IN LATVIA}

Latvia is situated in the north-eastern Europe; it shares the border with Estonia, Lithuania, Russia, and Belarus. The total area of Latvia is 64,589 square kilometers and the population of the country is 1.96 million.

According to the report of 2010 "Sustainable Strategy of Latvia until 2030" by Saeima of the Republic of Latvia, it is stated that by 202040 percent of the energy used by Latvia will be sourced by renewable energy resources and 50 percent - by 2030. Centralized thermal energy uses 80 percent of natural gas as a source to provide the inhabitants with heat and hot water during winter.

There are plans for improvements in the sector of renewable and safe energy as seen in Figure 2. 


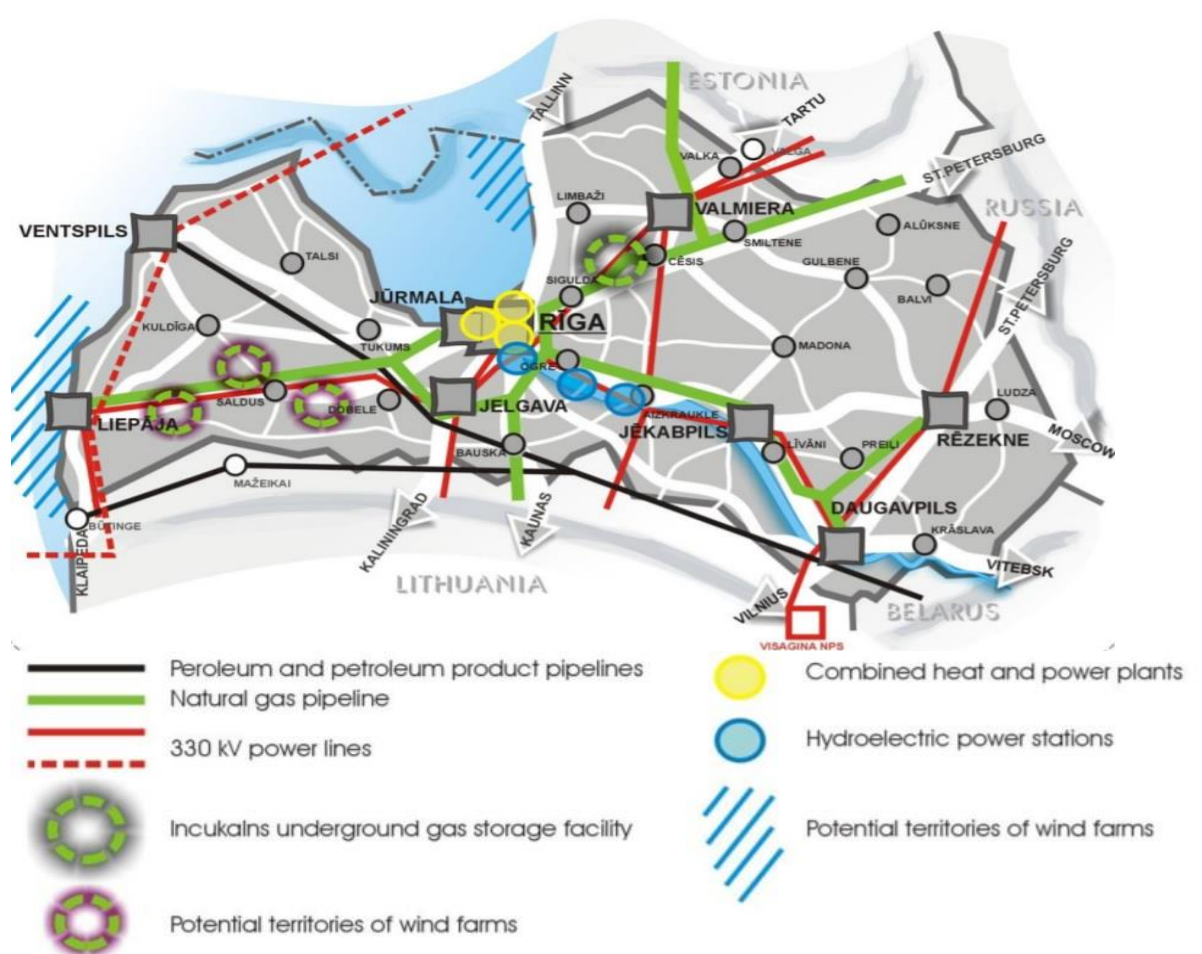

Fig. 2. Renewable and safe energy (2010) (Rubina, 2010, Riga City Sustainable Energy Action Plan 2010-2020).

As it is shown in the figure above, distribution network of renewable energy has covered the country. There are fewer petroleum and petroleum product pipelines compared to natural gas pipelines.

According to the papers developed by energy efficient and ecological housing and Central Baltic INTERREG IVA Program 2007-2013 "Energy efficient and ecological housing in Finland, Estonia and Latvia: current experiences and future perspectives" (2013), a state program for the period 2009-2010 coordinated by the Ministry of Economics invested 993,165 Euros in order to increase energy performance of dwellings. Latvia uses ERDF (European Regional Development Funds) to support improvement of energy performance of the buildings. The funding is used to recover the reconstruction or renovation costs by 50 to 60 percent and ERDF finances 49.8 Euro per meter square for proposed buildings under ERDF supervision. By October 2013, around 276 projects for refurbishment were completed.

During 2009-2013 within the program of Climate Change Financial Instrument, Latvia gained 200 million Euros by participating in international emissions trading. These funds were used to co-finance sustainable energy projects under the supervision of the Ministry of Environmental Protection and Regional Development and the Latvian Environment Investment Fund. By the end of September 2013, 2,082 projects were implemented. The co-financing rate varied from 35 till 85 percent, the projects were aimed to improve sustainable behavior of the building like reduction of carbon dioxide emission. 
Several examples of municipal projects co-funded by the Climate Change Financial Instrument in Latvia are listed below (Rubina, 2010, Riga City Sustainable Energy Action Plan 2010-2020):

- Strelnieki in Bauska;

- Several school buildings in Rezekne;

- Modernization of boilers, substituting fossil fuels with biomass, installing heat pumps and solar thermals in Jelgava.

According to "GBIG analysis" (2013), there are 16 sustainable buildings in Latvia, and they are:

- Aloja Business Centre, Riga;

- Upmalas Offices, Riga;

- Apartment Building Futuris;

- National Art Museum of Latvia "Riga Bourse";

- Ventspils Creative House, Ventspils;

- Kuldiga Town Hall and Complex, Kuldiga;

- Europa Business Centre, Riga;

- Apartment Building in Ropazu Street, Riga;

- Apartment Building in Ropazu Street, Riga;

- Riga Industrial Park office building, Riga;

- Passive Energy-Efficient Residential Buildings, Ventspils;

- Ambulatory Health Care Centre, Ventspils;

- Passive office building, Liepaja;

- Vecmajas, Dundaga Municipality;

- Student Dormitory of Ergli Vocational Secondary School, Ergli;

- Energy efficient passive house, Riga.

In addition, the new Construction Law of Latvia adopted in October 2014 solely focuses on the principles of architectural quality, engineering quality, transparency, sustainable construction and accessible environment. These new laws will help in developing better quality real estate objects.

\section{SUSTAINABLE REAL ESTATE OBJECTS IN RIGA}

Riga is the capital city of Latvia and it is also the largest city in the Baltic States. As mentioned in Sustainable Development Strategy of Riga until 2030 and Development Plan of Riga 2014-2020 (2014), the population of the city is 640,319 and the city area is 304 square kilometres, out of which 39 percent are green and blue territories.

The "Sustainable Development Strategy of Riga until 2030 and Development Plan of Riga 2014-2020 (2014)" released by the Riga City Council (Number 1173) focuses on improving the quality of Society, Urban Environment and Economy. The Society will improve in the areas of knowledge, skills, health and activity, which will help in overall economic development of Riga. In creating an ideal Urban Environment, the focus will be on introducing sustainable construction methods, natural environment of the city, better transportation methods and all aspects that affects living environment standards, labour and business environment. As a result, Economy of the city will grow because of the better public services and 
public infrastructure. Promoting Entrepreneurship will play a key role in economic development.

In "Riga City Sustainable Action Plan for 2010-2020" by Riga City Council (Number 1173) (2014), the use of renewable energy sources has been explained. The key sources available would be:

- Solid household waste for energy production by Getlini EKO;

- Biogas from Daugavgriga and Getlini EKO producing 9.4 Megawatt of electricity already, the plans are to increase production by 1 Megawatt;

- Biomass generated using 198,096 cubic meters of wood chips from Daugavgriga, Ziepniekkalns and Vecmilgravis;

- Geothermal energy using the 100-degree centigrade temperature of hot dry rocks at the depth of 2.75 kilometers;

- Heat pump installation in urban conditions in public buildings;

- $\quad$ Solar energy by making use of 1,109 kilowatt per square meter every year;

- Waste water heat for heat production for multi-apartment buildings with the help of district heating systems.

The financing for the implementation of this idea would be provided by various sources (Riga City Sustainable Energy Action Plan for 2010-2020, 2010) (Riga City Council, 2014):

- European Union Structural Funds and Cohesion Funds;

- Green Investment Schemes;

- Revolving Funds;

- Third party funding schemes: leasing, energy service companies, model for establishment of a municipal energy service company, public and private partnership;

- National and municipal aid mechanisms;

- EU aid program ELENA for development of measures.

The Most Sustainable Building and Project Competition held in Latvia 2014 brought many examples of sustainable practice use in constructing real estate.

The buildings that received the awards are:

- First Place: The Office building, 120Z Dzelzavas Street, Riga;

- Second Place: Žanis Lipke Memorial Museum building, 8 Balasta dambis, Riga

- Third Place: Jupiter Centre the office buildings, 7, k-1 Skanstes Street Riga

Compiling the ranking, the buildings were assessed according to such criteria as structure and construction materials, microclimate, heating, lighting and overall operation of the individual buildings after project completion. The office building which stood first had zero construction waste as all waste was sent for recycling. The total energy needed for a year to power heating, cooling and hot water is 17.5 kilowatt per square meter.

The projects are (GBIG: Most Sustainable Building Latvia, 2014):

- First Place: Felicity the residential building complex at 13 E. BirzniekaUpīša Street, Riga;

- Second Place: Riga Technical University Creative Industries Centre at 18 Āzenes Street, Riga; 
- Third Place: The residential building with social care apartments at 7 Piena Street, Riga.

The project, which stood first in this competition, was built in a way that it had minimal amount of scrap waste. Even though the project was built in a narrow location, the contractor managed to make playgrounds, lawns and relaxation space for guests or residents. The project successfully implemented the idea of rainwater harvesting which later will be used for watering the plants in the garden and other things. The project does not use city's water supply system as the water source, ground water is used instead (GBIG, 2014). Discussion and results are presented in the next part.

\section{DISCUSSION AND RESULTS}

According to the analysis of various sources, Latvia is progressing towards a sustainable future but is still very much behind Sweden. The economic statistics of these two countries are incomparable, which attests that these two countries currently are at a different stage of development. The comparison was made according to the following criteria (Kairans, D. (2016). Latvia Real Estate Market Overview, Research and Forecast Report. Colliers International; Ministry of Economics. (June 2016). Republic of Latvia, Economic Development of Latvia; Focus Economics. (September 2017). Latvia Economic Outlook: Latvia Economic Data; Focus Economics. (September 2017). Sweden Economic Outlook: Sweden Economic Data; Santander Trade. (October 2017). Latvia: Foreign Investment; Santander Trade (October 2017). Sweden: Foreign Investment; Bradbury, D., Harding, M., \& Lahittete, M. (2016). OECD: Organisation for Economic Cooperation and Development, Revenue Statistics of Sweden; Bradbury, D., Harding, M., \& Lahittete, M. (2016). Revenue Statistics of Latvia):

\section{- Property Taxes:}

In the year 2014, Latvia collected 271 million USD and in the same year Sweden collected 4,805 million USD in the form of property taxes. Property taxes on contributes $4 \%$ of the total taxes in Latvia, which grew by $1 \%$ from the previous year 2013, whereas in Sweden property taxes contributed $3 \%$ of the total taxes.

- Foreign Direct Investment (FDI):

In 2011, the Foreign Direct Investment (FDI) in Latvia amounted to 2,280 million Euros, out of which $24.4 \%$ was contributed by real estate investment. In 2016, the investment changed to 13,000 million Euros, of which $12.51 \%$ was real estate investment of total FDI of 2016. The most investment done by a country to Latvia was Sweden $15.69 \%$, which was 2,120 million Euros in 2016. Foreign Direct Investment in Sweden was 17,495 million Euros in the year 2016. The country was ranked $9^{\text {th }}$ out of 190 countries in Doing Business Report issued by the World Bank. But Sweden's FDI in the real estate sector was less compared to other sectors like manufacturing $30 \%$, transport equipment $22 \%$, legal, professional, scientific and technical activities $15 \%$, oil and chemical products $11 \%$ and trade maintenance $10 \%$.

- Real Estate Loans: 
In Latvia, the house purchase support program for new families is continuing to expand the real estate market, the household demand for loans also improved in 2016. New household loans for house purchase (excluding renegotiated loans) increased by $38.0 \%$ in 2016, whereas consumer crediting increased by $29.3 \%$. The interest rate on new household loans for house purchase in Euro declined from $3.1 \%$ in 2015 to $3.0 \%$ in 2016.

- House Price Growth:

House prices in Latvia degraded to $-3.7 \%$ in 2015 from 2014's 5.3\% and 2013's 6.2 \%. House prices in Sweden kept on rising from 2013's 4.7 \%, 2014's $8.6 \%$ and 2015's $11.9 \%$. Sweden's house price growth remained strong and kept rising compared to Latvia, where prices started declining from 2015. Key comparisons of two cities are shown in Table 1.

Table 1. Key Comparisons [Based on the previous findings and Siemens (n.d.)]

\begin{tabular}{|c|c|c|}
\hline Indicators & Riga & Stockholm \\
\hline City area (square kilometers) & 304 & 188 \\
\hline Population & $640,319(2015)$ & $\begin{array}{r}789,024 \text { (2007), } 900,000 \\
(2015)\end{array}$ \\
\hline Rank for carbon-dioxide emissions & $\begin{array}{r}15 \text { (5.4 tonnes, } \\
2003)\end{array}$ & $\begin{array}{r}2(5.4 \text { tonnes, } 1990 ; 3.6 \\
\text { tonnes, 2007) }\end{array}$ \\
\hline $\begin{array}{l}\text { Energy consumption of residential } \\
\text { buildings }\end{array}$ & $\begin{array}{r}923.81 \mathrm{MJ} / \mathrm{m}^{2} \\
(2007)\end{array}$ & $769.87 \mathrm{MJ} / \mathrm{m}^{2}(2007)$ \\
\hline $\begin{array}{l}\text { Percentage of renewable energy } \\
\text { consumption of the city }\end{array}$ & 7.09 & 20.08 \\
\hline Percentage of share of waste recycled & 8 & 31 \\
\hline
\end{tabular}

The population of Riga is declining year by year, whereas Stockholm is gaining residents every year. Riga lost around 80,000 residences in the last ten years and Stockholm added 120,000 residences in that same period. In 1990, Stockholm emitted 5.4 tonnes carbon-dioxide, which is similar to Riga's 2003 emissions. In 2007, Stockholm's carbon-dioxide emissions reduced to 3.6 tonnes. Stockholm was termed the Most Sustainable Country in the World in 2013 (Environmental Leader, 2013) because of the level of sustainable practices, which were practiced for many years as compared to Riga, followed by the amount of money invested and the current market situation. By analyzing differences in real estate object development in two northern capitals, the authors make the following conclusions.

\section{CONCLUSION}

Riga and Stockholm are two northern capitals of Europe having cultural importance in their own unique way.

In the report of 2003 named "A Swedish Strategy for Sustainable Development: Economic, Social and Environmental 2003" by the Swedish Ministry of the Environment, there are common directions with the report "Sustainable 
Development Strategy of Riga until 2030 and Development Plan of Riga 20142020" and "Development Program of Riga", which was drawn up in 2014.

Both reports share similar ideas and close aims on improving social, economic and environment aspects to make the regions more livable and attractive for business. However, in Riga this plan was adapted later. Certainly, the idea is right as Swedish cities are leading examples of sustainable development strategies, which can recommend some directions for sustainable development of real estate in cities.

\section{REFERENCES}

AREIM. (n.d.). Sustainable building Examples. Retrieved from http://www.areim.se/in-english/aboutareim/sustainability/examples-of-our-projects

Bergström, G., \& Save-Öfverholm, U. (2011). Swedish Sustainable Building released on World Sustainable building conference, held in Helsinki 2011. Retrieved from http://www.formas.se/PageFiles/5460/Formas_SB11_brochure.pdf

Bradbury, D., Harding, M., \& Lahittete, M. (2016). OECD: Organisation for Economic Co-operation and Development, Revenue Statistics of Sweden. Retrieved from https://www.oecd.org/tax/revenue-statistics-sweden.pdf

Bradbury, D., Harding, M., \& Lahittete, M. (2016). Revenue Statistics of Latvia. Retrieved from https://www.oecd.org/tax/tax-policy/revenue-statistics-latvia.pdf

City of Stockholm Executive Office. (2007). Stockholm City Council, Vision 2030 A Guide to the Future for Stockholm. Retrieved from http://international.stockholm.se/globalassets/ovriga-bilderoch-filer/framtidsguiden_eng.pdf

Energy Efficient and ecological housing. (2013). Central Baltic INTERREG IVA Programme 20072013, Energy Efficient and ecological housing in Finland, Estonia and Latvia: Current experience and future perspectives. Retrieved from

http://www.bef.lv/fileadmin/media/Publikacijas_Climate/2013_Energy_efficient_and_ecological _housing_in_Finland_Estonia_and_Latvia_current_experiences_and_future_perspectives.pdf

Environmental Leader: News and Best Practices for Commercial \& Industrial Environmental Professionals. (2013). Sweden The Most Sustainable country in the World. Retrieved from https://www.environmentalleader.com/2013/08/sweden-most-sustainable-country-in-the-world/

European Commission. (2016). European Semester Thematic Factsheet: Banking Sector and Housing. Retrieved from https://ec.europa.eu/info/sites/info/files/european-semester_thematic-factsheet_ banking-sector-housing_en.pdf

European External Action Service. (2017). Delegation of the European Union to India and Bhutan, The Sustainable Housing Leadership Consortium launches \#greenhomes campaign for $20 \%$ of India's new homes to become green by 2022 Retrieved from https://eeas.europa.eu/delegations/ india_en/30112/The $\% 20$ Sustainable $\% 20$ Housing\%20Leadership $\% 20$ Consortium $\% 20$ launches $\% 20$

Eurostat Statistical Books. (2013). Sustainable Development in European Union, 2013 monitoring report of the EU sustainable development strategy. Retrieved from http://ec.europa.eu/eurostat/documents/3217494/5760249/KS-02-13-237-EN.PDF

Fabian Zuleeg. (June 2010). European Economic Sustainability Index. European Policy Centre Retrieved from http://www.epc.eu/documents/uploads/pub_1127_eesi.pdf

Focus Economics. (September 2017). Latvia Economic Outlook: Latvia Economic Data. Retrieved from https://www.focus-economics.com/countries/latvia

Focus Economics. (September 2017). Sweden Economic Outlook: Sweden Economic Data. Retrieved from https://www.focus-economics.com/countries/sweden

GBIG: Green Building Information Gateway. (2014). Most Sustainable Buildings in Latvia. Retrieved from http://www.gbig.org/collections/14184/activities

Kairans, D. (2016). Latvia Real Estate Market Overview, Research and Forecast Report. Colliers International. Retrieved from http://www.liaa.gov.lv/files/liaa/attachments/2_colliers_latvia_real_ estate_market_overview_2016.pdf 
Ministry of Economics. (June 2016). Republic of Latvia, Economic Development of Latvia. Retrieved from https://em.gov.lv/files/tautsaimniecibas_attistiba/zin/2016_jun_eng.pdf

Riga City Council (Number 1173). (2014). City Development Department, Sustainable Development Strategy of Riga until 2030 and Development Plan of Riga 2014-2020. Retrieved from

http://www.rdpad.lv/wp-content/uploads/2014/11/ENG_STRATEGIJA.pdf

RobecoSAM. (2016). Country Sustainability Ranking Update. Country sustainability ranking - April 2016, dimension \& total sustainability scores Retrieved from http://www.robecosam.com/images/Country_Ranking_Update_May_2016.pdf

Rubina, M. (2010). Riga City Council, Riga City Sustainable Energy Action Plan for 2010-2020. Retrieved from http://www.rea.riga.lv/files/MR_ricibas_plans_prezentacija_EN.pdf

Santander Trade. (October 2017). Latvia: Foreign Investment. Retrieved from https://en.portal.santandertrade.com/establish-overseas/latvia/investing

Santander Trade. (October 2017). Sweden: Foreign Investment. Retrieved from https://en.portal.santandertrade.com/establish-overseas/sweden/foreign-investment

Siemens. (n.d.). European Green City Index of Riga. Retrieved from https://www.siemens.com/entry/cc/features/greencityindex_international/all/en/pdf/riga.pdf

Swedish Institute, Business Sweden, VisitSweden and the Swedish Government Offices (2016). Sweden Sverige (Sweden.se), Seven Examples of Sustainability in Sweden. Retrieved from https://sweden.se/nature/7-examples-of-sustainability-in-sweden/

Swedish Institute, Business Sweden, VisitSweden and the Swedish Government Offices (2016b). Sweden Sverige (Sweden.se). Sustainable Living in Sweden. Retrieved from https://sweden.se/nature/sustainable-living/

The Swedish Ministry of the Environment. (2003). A Swedish Strategy for Sustainable Development: Economic, Social and Environmental 2003. Retrieved from http://www.government.se/contentassets/3f67e0b1e47b4e83b542ed6892563d95/a-swedishstrategy-for-sustainable-development-summary

United Nations. (September 2015). Transforming our World: The 2030 Agenda for Sustainable development. Retrieved from https://sustainabledevelopment.un.org/content/documents/212520 $30 \% 20$ Agenda\%20for\%20Sustainable\%20Development $\% 20$ web.pdf

\section{AUTHORS' SHORT BIOGRAPHIES}

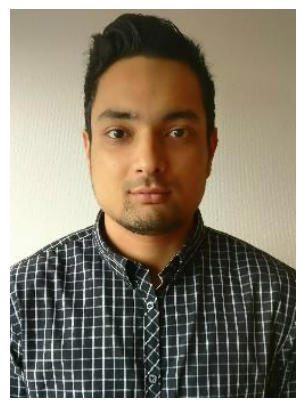

Ankit Mishra, a Civil Engineer, graduated from the Mahatma Jyoti Rao Phoole University in India in 2014. Currently, he is obtaining a Master degree at Riga Technical University at the program "MSc. Civil Construction and Real Estate Management". He is also ongoing Erasmus Traineeship at KTH Royal Institute of Technology for his Master Thesis in his final semester of Master studies.

He has previously worked for private companies in India as a Civil Engineer which are Raj Agarwal \& Associates, P.R. Promoters \& Developers Pvt. Ltd. and has also worked on individual private projects in India as self-employed for less than a year. He has also worked as an Intern at an online real estate portal named Liveonriviera.com as a Business Developer and worked as a real estate agent at Dream Property while studying at Riga Technical University for the period of six months.

$\mathrm{He}$ is interested in research on development of sustainable real Estate, green buildings, sustainable construction management, economic sustainability, urban sustainable development, real estate market, etc. 


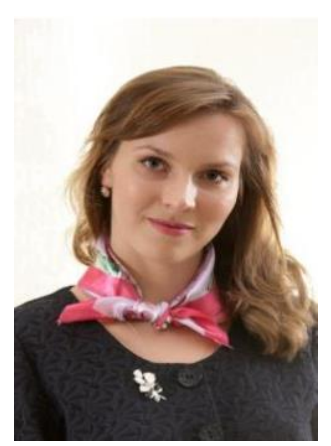

Linda Kauškale, $\mathrm{Mg}$. oec., is a lecturer, a PhD student and an assistant researcher of the Institute of Civil Engineering and Real Estate Economics, Faculty of Engineering Economics and Management, Riga Technical University. She with distinction obtained Professional Master Degree in Civil Construction and Real Estate Management, has the qualification of Real Estate Economist and extensive practical experience. She has participated in international scientific conferences and seminars in Latvia, Germany, United Arab Emirates, Singapore, Malaysia, Lithuania etc. Her main research areas are sustainable real estate market concept, sustainable cities and sustainable construction, green buildings, macroeconomic analysis, business cycle, decision-making, environmental

development, etc. She is DGNB (Deutsche Gesellschaft für nachhaltiges Bauen - German Sustainable Building Council) Registered Professional. In 2016, she was a Professional Member of Industrial Engineering and Operations Management Society. In fall 2016, she was Deutsche Bundesstiftung Umwelt (German Environmental Foundation) Scholarship holder. In autumn 2013, she was a FIABCI scholar.

ORCID iD: http://orcid.org/0000-0002-0280-2977 